\title{
Bamboo as an Eco-friendly Material for Use in Aquaculture Industry in Malaysia
}

\author{
Razak Wahab \\ School of International Tropical Forestry \\ Universiti Malaysia Sabah, Malaysia \\ Othman Sulaiman \\ Universiti Sains Malaysia (USM) \\ 11800 Minden, Penang, Malaysia \\ Aminuddin Mohamad \\ School of International Tropical Forestry \\ Universiti Malaysia Sabah, Malaysia \\ Hashim W. Samsi \\ Forest Research Institute Malaysia (FRIM) \\ Kepong, 52109 Kuala Lumpur, Malaysia \\ Izyan Khalid \\ School of International Tropical Forestry \\ Universiti Malaysia Sabah, Malaysia
}

\begin{abstract}
Aquaculture industry has contributed $10 \%$ which equal to 1,400 metric ton of the overall fish production in Malaysia. It has undergone a transition stage from small scale family oriented business to large scale operations managed by corporate bodies. Currently, the cost of constructing the basic structure of a floating cage using plastic drums or other foreign materials which is considered as a non-environmental friendly is rather expensive. This also means that such business ventures would not be affordable by the rural community. With the introduction of bamboo as the material in constructing floating cages, cost could be reduced and maintenance should be made much easier. Rural community is expected to benefit from this cost-saving material by setting up aquaculture business through village cooperatives. This paper outlines the concept of using bamboo as the main building material in the fishing industry. The cost and benefit of substituting foreign material with bamboo is examined too.
\end{abstract}

Keywords: Aquaculture, Floatation material, Bamboo, Economic aspect

\section{Introduction}

Aquaculture industry in Malaysia has undergone a transition stage from small scale family oriented business to large scale operations managed by corporate bodies. This is discernible from the total aquaculture production of 1400 metric tons (valued between RM 700-900 million), compared to the overall fish production of 1.4 million metric tons in 2004. Though aquaculture production constituted only $10 \%$ of the total fish production, with the bulk of the fish production or closed to $90 \%$ came from captured fisheries sector. With the declining catch rates from coastal and inland fisheries, there is a need to promote extensive development of aquaculture industry in the country.

As a cheap source of animal protein fish is considered an important food item by local people. Due to easy access to fish and fish products, Malaysia is among the country with highest fish consumption in the world. Estimate put that on average per capita consumption was $49 \mathrm{~kg}$ per capita in year 2000. This was further increased to $53 \mathrm{~kg}$ per capita in the year 2005 and is expected to rise further to $56 \mathrm{~kg}$ per capita in the year 2010. The important of fish as food is further reflected in expenditure of the household. On average this was about 20 percent of their food budget. With the increase in number of population of the country and increase in health consciousness among the people apparently current local 
production will not able to meet the goal of self sufficiency within these coming years. Basically, the self sufficiency was only 89 percent in year 2000. This was slightly increased to about 90 percent in year 2005 and expected to be slightly increase to 94.3 percent in 2010 (Utama and Ahmad, 2005).

Aquaculture is a farming of aquatic organisms in salt, brackish or fresh water. Fishes, crustaceans, mollusks, algae, and aquatic plants are among popular variety of aquatic organisms that are produced through aquaculture. Unlike capture fisheries, aquaculture requires deliberate human intervention in the organisms' productivity and results in yields that exceed those from the natural environment alone. Such intervention includes stocking water with juvenile organisms, fertilizing the water, feeding the organisms, and maintaining water quality. Aquaculturists need to manage their production to ensure that water quality does not deteriorate and become stressful to the culture organisms. Aquaculture is considered an agricultural activity, despite the many differences between aquaculture and terrestrial agriculture. Aquaculture mainly produces protein crops, while starchy staple crops are the primary products of terrestrial agriculture.

The present costs of constructing and maintaining the floating rafts for cage culture sheltered inshore water are quite high. As a result only those with big capital investment can afford to get involved in the business while the rural communities staying near the coastal areas are left behind.

The cost of constructing a single floating raft with four cages consisting of several fish species and using timber as the basic material is around RM2,500.00 (Shukur et al. 1992). This figure multiplied by 20 fish-cages (an economic number of cages for profitable venture in business) will come to a total of RM50,000.00. Therefore a minimum of RM50,000.00 is required to start a business in aquaculture industry. Kamaruzaman and Rabihah (1989) quoted a much lower cost of about RM43,128 for 40 units of floating cages (RM1,078.20 per cage). Another study quoted an average cost of RM 2,071 per cage (Azlan and Rahim, 1982). However, the cost of building up the floating cage could easily be reduced if timber and plastic or polystyrofoam could be substituted with other cheap but durable material such as bamboo.

The type of aquaculture system that can be adapted using bamboo as the floating material are penaeid or marine prawn culture, crab culture or fattening, culture of coastal fin-fishes in brackish water and culture of coastal finfishes in net-cages.

\section{Bamboo and its preservation for marine use}

Bamboo is well known for its strong and versatile properties due to its incredible strength. However, the selection of the right species, age and preservative treatment is very important especially for marine uses. Bamboo is susceptible to micro-organism and fungal attacks. The durability of bamboo is dependent on the environmental conditions in which it is exposed. To prolong its service life, bamboo needs to be treated with preservatives. This is particularly true since the untreated bamboo has a service-life of less than one year if exposed to sea water (Liese, 1985). With proper treatment, however, it can be expected to last up to 3-5 years depending on the age and species.

Although bamboo has been used as a construction material in marine environment for centuries, not much research has been conducted to seek ways of protecting it from the activities of degrading marine organisms. Although micro-organisms deteriorate the surfaces of bamboo when exposed to seawater, the primary agents of attack are the marine wood boring animals - the mollusks and crustaceans. It seems that the establishment of superficial microbial decay will enhance the settlement of marine borers on the bamboo surface. This being so, the problem of protecting bamboo from attack must also be considered in terms of the softening of bamboo surfaces by bacteria and fungi.

There are many ways to treat the bamboo, but for effective treatment, the bamboo is treated with selected preservatives such as creosote, copper-chrome-arsenic (CCA), copper-chrome-boric (CCB), ammoniacal-copper-arsenite (ACA) and zinc-copper-chrome-arsenic (ZCCA) (Georgia, 1982) by means of high pressure sap-displacement method or pressurized treatment. However, the use of heat treatment process is another alternative that is highly recommended here to enhance the bamboo durability (Razak et al. 2005). Furthermore this technique is eco-friendly and does not pose threat to the environment.

Bamboo is relatively cheap and adaptable for long service marine uses. It has many applications and has been used in the fishing industry for decades, although no documented information is available.

\section{Construction of bamboo floating rafts and cages}

\subsection{Frame of raft}

The bamboo frame of the raft floats on the surface using bamboo for the flotation.

i. Types of bamboo with service life 18 -36 months (after heat treatment, chemical treatment or painted with marine paints):

a) Gigantochloa scortechinii (buluh semantan),

b) Bambusa vulgaris (buluh minyak), 

c) Bambusa blumeana (buluh duri),
d) Gigantochloa levis (buluh beting).

ii. Materials for frame:

a) Bamboo for frame (20' length),

b) Floor planks (20' length),

c) Side planks (20' length),

d) Bolts and nuts (36 pieces),

e) Nails (2 kg),

f) Nylon strings.

\subsection{Flotation}

As has been mentioned, bamboo is used for the purpose of floatation, its durability and ease in which it can be maintained and replaced. The current price of bamboo pole is between RM2.00 to RM5.00 for one culm (15 m).

\subsection{Cages}

This section deals with the cutting and shaping of the netting to form four net cages, each $3 \times 3 \times 3 \mathrm{~m}$.

i. $\quad$ Netting

Knotted polyethylene is recommended and the following specifications regarding the ply and the mesh size are equated with various fry stocking sizes.

\begin{tabular}{ccc}
\hline Size for fry $(\mathrm{cm})$ & Mesh size $(\mathrm{cm})$ & Ply \\
\hline $09-12$ & 2.5 & 18 \\
$10-22$ & 2.5 & 21 \\
$25-32$ & 3.8 & 30 \\
more than 32 & 6.3 & 48 \\
\hline
\end{tabular}

ii. Cage construction

For stocking size of $10-22 \mathrm{~cm}$, polyethylene net with a $2.5 \mathrm{~cm}$ mesh and a ply of 21 is suggested. For one raft with 4 cages, $30 \mathrm{~m}$ of netting with a width of 300 mesh is required.

\subsection{Anchorage}

To maintain the raft and the nets in position, anchorage is necessary. For this purpose concrete weights are used.

Figures 1 and 2, shows a single bamboo fish floating cage.

\section{Economic aspect}

The current cost of constructing a single floating raft consisting of four (4) cages is RM2,620.00. This includes the cost of buying timber, netting as well as wages paid to laborers involved in constructing the cage. The cost breakdown is given in Table 1. an increase especially in timber price from an average of only RM500/ ton to RM8700/ ton has made the cost of constructing the cage much more costly than before.

Detailed breakdown of items required in setting up commercial cage culture is provided in Table 2. Except for the cost of the floating cage, the rest of the costs involved in the initial investment of the project are adopted from Kamaruzaman and Rabihah (1989). With a total initial investment of about RM102,900, the project is expected to generate a Net Present Value (NPV) of RM75,720 after 10 years of operation. The Internal Rate of Return (IRR) would be about $28 \%$. The IRR was much lower than the assessment made by Kamaruzaman and Rabihah (1989). They estimated an IRR of about $55 \%$.

If bamboo is used as a substitute for timber structure as well as floats, then for every floating raft we could save about RM457.20. With the new cost structure, not only will it save the initial investment of building the floating cage but also help to improve the IRR of the project. This will make the project more lucrative than other investments. The total cost that could be saved by substituting with bamboo as building material is estimated to be about $18 \%$. Table 3 provides the cost of substituting timber with bamboo.

\section{Advantages}

The advantages of using bamboo are:

1. Cheap and readily available; 
2. Easy to maintain/ replace;

3. Easily to dispose once damaged; and

4. No threat to environment.

\section{Recommendations and conclusion}

From the information and analyzed data presented above, it was found that bamboo could easily substitute timber as the basic material in aquaculture and other fishing industries. The costs involved are much cheaper compared to timber.

In the face of diminishing returns from our heavily-exploited natural fish resources, bamboo aquacultures with the necessary technical and financial inputs from both government and the private sectors can play an increasingly important role in the production of protein food supply within the country, in generating employment opportunities, and in gaining a considerable amount of foreign exchange through the export of some aquaculture products and saving on fish import.

\section{References}

Anonymous. 2004. Annual fisheries statistics. Department of Fisheries, Ministry of Agriculture and Agro-based Industry Malaysia. Pp 263.

Azlan, H. \& Rahim, G.Y. 1982. Construction of floating rafts for cage culture. Field document 1, Lembaga Kemajuan Ikan Malaysia.

George, J. 1982. Preservative treatment of bamboo. In Preservation of Timber in the Tropics. Martinus Nijhoff/ Dr. W. Junk Publishers.

Kamaruzaman, S. \& Rabihah, M. 1989. Economics of Marine Cage Culture in Kukup, Johor. Kertas Pengembangan Perikanan, Bil. 148, Jabatan Perikanan, Kementerian Perikanan Malaysia.

Liese, W. 1985. Bamboos - Biology, Silvics, Properties, Utilization. Schriftenreihe der GTZ, No. 180.

Ong, K.S. 1990. Aquaculture Development in Malaysia in the 1990's. Risalah Perikanan Bil. 51, Jabatan Perikanan Kementerian Pertanian Malaysia.

Razak, W., Aminuddin, M., Hashim, W.S. \& Othman, S. (2005). Effect of heat treatment using palm oil on properties and durability of Semantan bamboo. Journal of Bamboo and Rattan. Vol. 4, No.3. July 2005, pp. 211-220 (10). ISSN: 1569-1568, International Network for Bamboo and Rattan.

Shukur, N., Azmy, M., Mohari, M.T. \& Razak, W. 1992. Potential use of bamboo for fish rearing cage at Johore fishing village. National Bamboo Seminar, FRIM, Kepong, Kuala Lumpur. 2 - 4 Nov. 1992.

Utama, C.M. \& Ahmad Adnan, N. 2005. Trash fish production and national fish feed requirement in Malaysia. Working paper presented at the "Regional Workshop on Low Value Trash Fish in the Asia-Pasific Region. Hanoi, Vietnam, 7-9 June 2005.

Table 1. Fish production from marine landings and marine aquaculture in the year 2000 to 2004

\begin{tabular}{cccccccc} 
& \multicolumn{2}{c}{ Landing } & \multicolumn{2}{c}{ Aquaculture } & \multicolumn{2}{c}{ Total } \\
\cline { 2 - 7 } Year & $\begin{array}{c}\text { Volume } \\
\text { (metric ton) }\end{array}$ & $\begin{array}{c}\text { Value } \\
\text { (RM million) }\end{array}$ & $\begin{array}{c}\text { Volume } \\
\text { (metric ton) }\end{array}$ & $\begin{array}{c}\text { Value } \\
\text { (RM million) }\end{array}$ & $\begin{array}{c}\text { Volume } \\
\text { (metric ton) }\end{array}$ & $\begin{array}{c}\text { Value } \\
(\text { RM million) }\end{array}$ \\
\hline 2000 & $1,285,696$ & 4399.23 & $117,205.56$ & 665.34 & $1,402,901.56$ & $5,064.57$ \\
2001 & $1,231,289$ & 4166.11 & $133,562.79$ & 958.01 & $1,364,851.79$ & $5,124.12$ \\
2002 & $1,272,078$ & 4206.81 & $145,439.81$ & 843.49 & $1,417,517.81$ & $5,050.30$ \\
2003 & $1,283,256$ & 4013.62 & $146,926.82$ & 931.09 & $1,430,182.82$ & $4,944.71$ \\
2004 & $1,331,645$ & 4241.45 & $146,668.04$ & 903.38 & $1,478,313.04$ & $5,144.83$ \\
\hline
\end{tabular}

Source: Anoymous 2004. 
Table 2 . The current cost in constructing a single fish floating cage

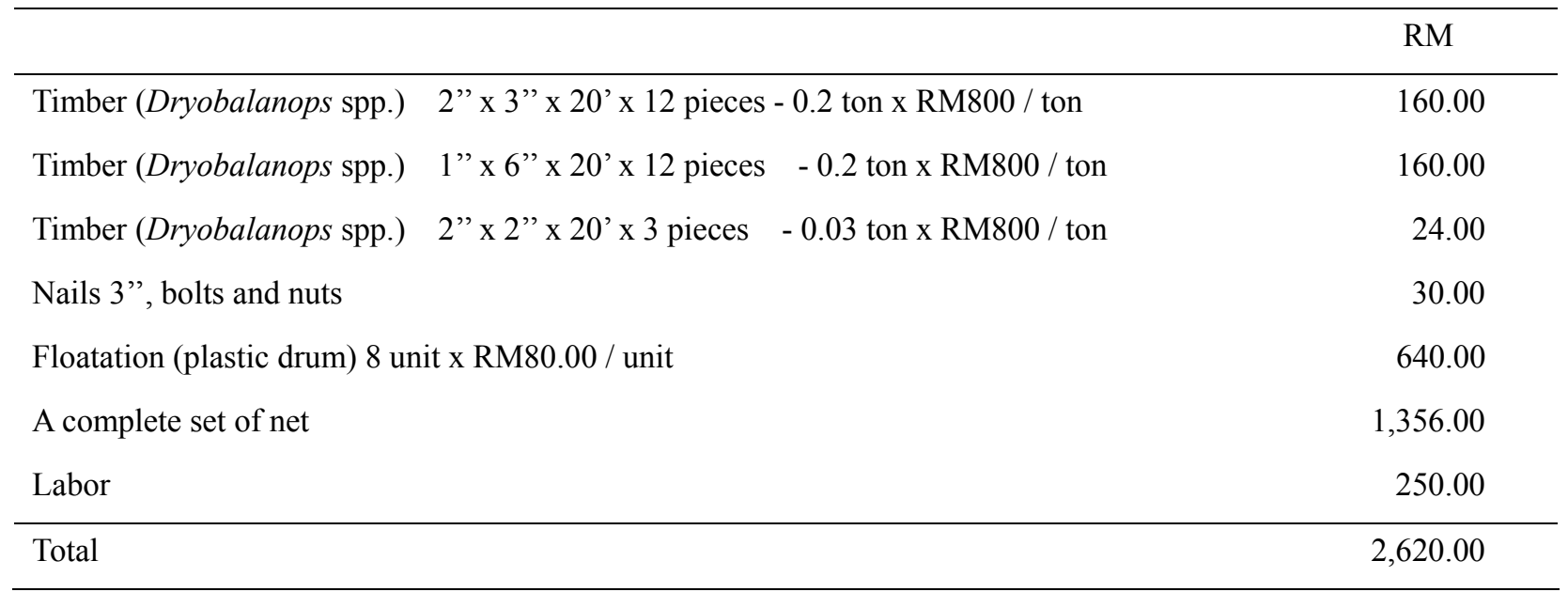

Table 3. Initial investment of commercial cage culture*

\begin{tabular}{lcccc}
\hline Variable & Unit Cost & Total unit & Total cost (RM) & Economic life (yr) \\
\hline Floating cage (complete unit) & 2260 & 40 & 90400 & 10 \\
High pressure pump & 4500 & 1 & 4500 & 6 \\
Feed chopper/blender & 2000 & 1 & 2000 & 6 \\
Generator & 2000 & 1 & 2000 & 6 \\
Fish boxes & 250 & 2 & 500 & 6 \\
Boat & 1000 & 1 & 1000 & 6 \\
Out-board engine & 2000 & 1 & 2000 & 5 \\
Other equipment & 500 & & 500 & 5 \\
\hline Total & & 102,900 & \\
\hline
\end{tabular}

* Kamaruzaman \& Rabihah 1989.

Table 4. The cost of using bamboo in constructing a single fish floating cage

\begin{tabular}{lr}
\hline & RM \\
\hline Bamboo pole 20' in length - 32 pieces x RM2.00 / pole & 64.00 \\
Timber (Dryobalanops spp.) 1" x 6" x 20' x 12 pieces - 0.2 ton x RM800 / ton & 160.00 \\
Nail 3", nylon rope & 60.00 \\
Bamboo for floatation 4' - 288 pieces x RM0.60 / piece & 172.80 \\
A complete set of net & $1,356.00$ \\
Bamboo heat treatment to enhance durability & 500.00 \\
Labor & 250.00 \\
\hline Total & $2,562.80$
\end{tabular}




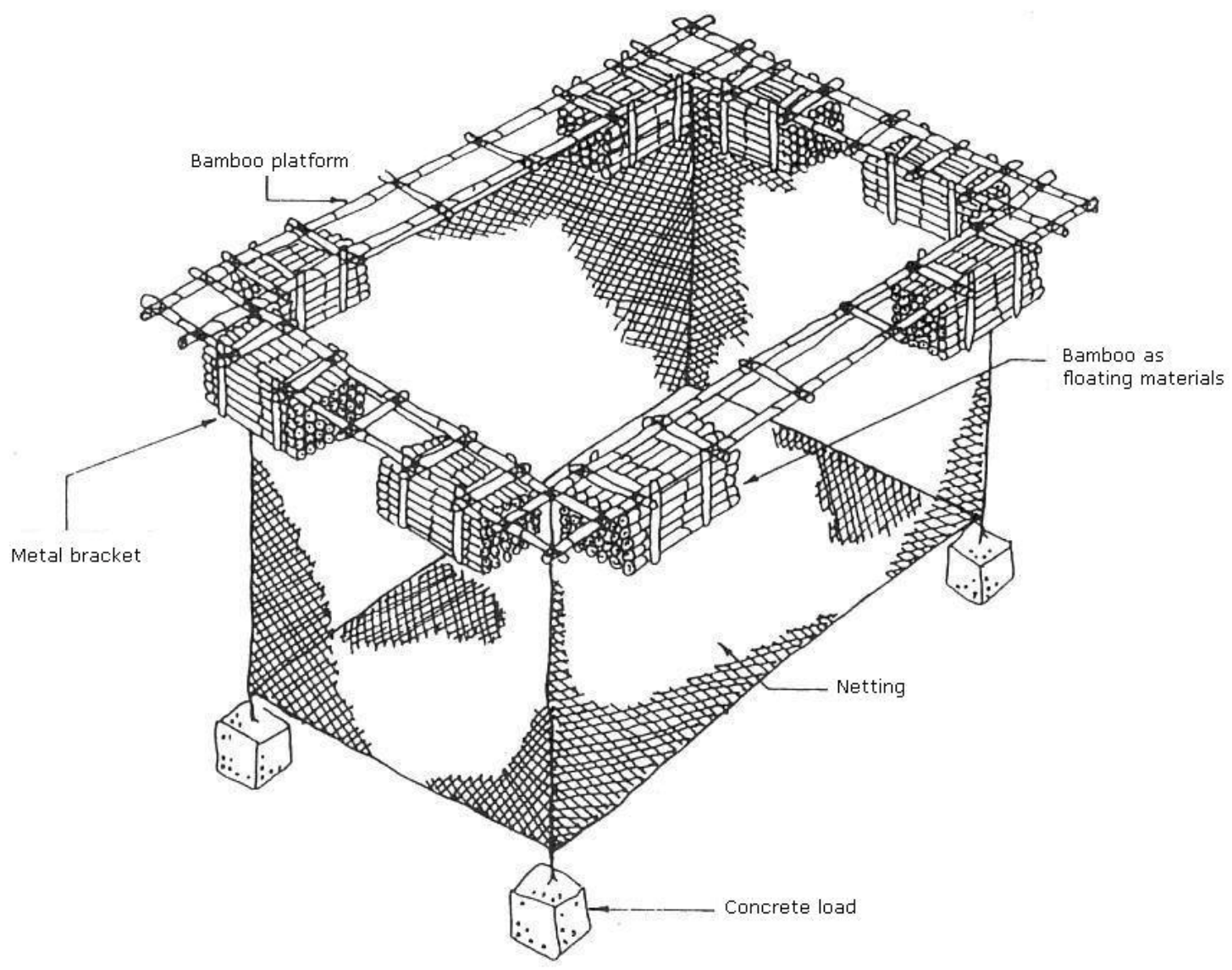

Figure 1. Fishing cage with bamboo used as floatation materials
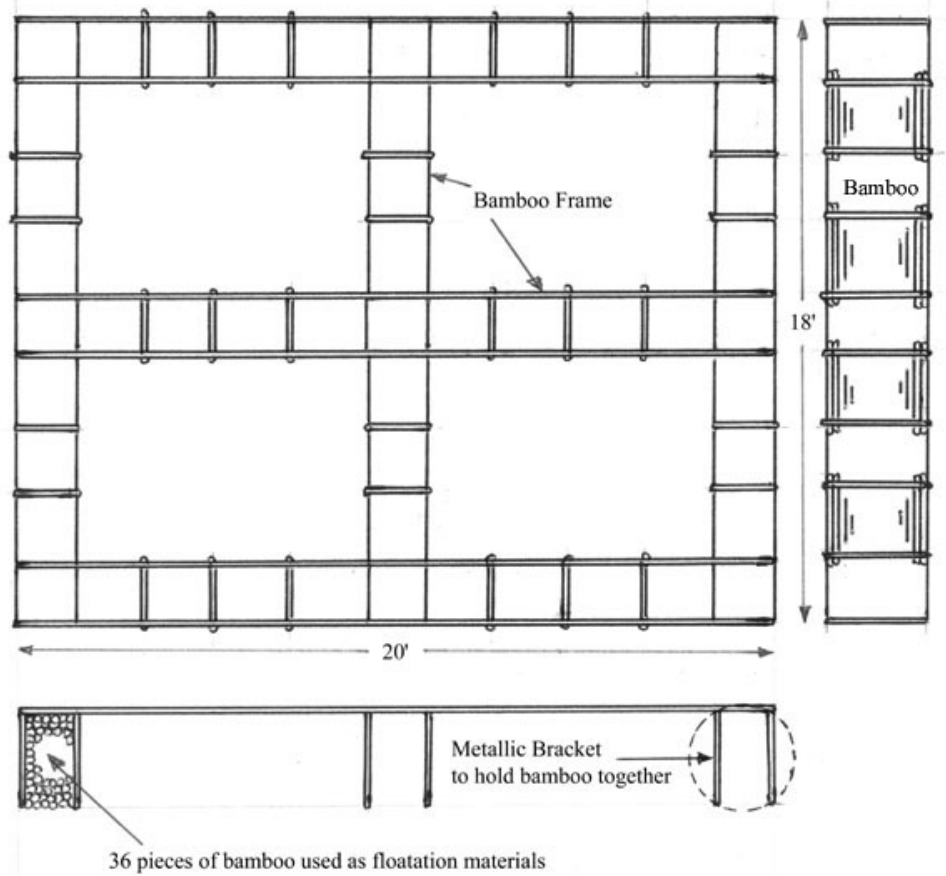

Figure 2. The plan (top) and side (bottom) elevation of bamboo fishing cages. 